УДК 159.954.2:[613.88+616.89-008.442]

DOI:10.26565/2410-1249-2018-10-10

\title{
SEXUAL FANTASIES: REVIEW OF MAJOR SCIENTIFIC STUDIES
}

\author{
Valeria Palii \\ Kyiv National Linguistic University \\ Velyka Vasylkivska str. 73, Kyiv, 03680, Ukraine \\ E-mail:valeria.tsykhonya@gmail.com, https://orcid.org/0000-0001-5916-2213
}

This publication aims at analyzing major classic and current research on sexual fantasies. A new perspective on this phenomenon that understands sexual fantasies as an integral part of a human's sexual life, that includes various mental visions and impressions which are perceived by a person as sexual and evoke arousal, is introduced. Main perceptions regarding their development patterns, including a psychoanalytic framework, development of fantasies as a result of learning, a correlation between the frequency of sexual fantasies and sex hormones levels are presented. It was established that sexual fantasies constitute a part of cognitive processes that take a direct part in a cycle of a sexual reaction formation. New functions of sexual fantasies were outlined; they include reinforcement of sexual arousal, stress reduction, escape from reality, forecasting, self-esteem boost and others. Key contextual aspects, such as fantasies of a romantic nature, sexual experimenting fantasies, fantasies with a concept of submission or dominance, sadomasochist fantasies, voyeurism, promiscuity, group sex themed fantasies or ideas of a permanent partner change, are revealed. The difference between a female and a male type of fantasizing is also described. Main problems associated with sexual fantasizing are revealed: the presence of obsessive fantasies, deviant fantasies, peculiarities of fantasizing among persons with traumatic experience, a specific correlation between nature of sexual fantasies and personal features. Fundamental psychotherapeutic methods of dealing with sexual fantasies are briefly examined: aversion psychotherapy, positive reinforcement of the desired experience, eye movement desensitization and reprocessing, psychoanalytic interpretation of a content of fantasies, emotion extraction method.

KEYWORDS: sexual fantasies, functions of sexual fantasies, the content of sexual fantasies, sexual health

\section{СЕКСУАЛЬНІ ФАНТАЗЇ: ОГЛЯД ОСНОВНИХ НАУКОВИХ ДОСЛІДЖЕНЬ}

Палій В.С.

Київський національний лінгвістичний університет вулиия Велика Васильківська, 73, Київ, 03680, Україна

Дана публікація присвячена аналізу основних класичних та новітніх досліджень вивчення сексуальних фантазій. Представлено сучасне розуміння даного феномену, згідно з яким сексуальні фантазії - це невід’ємний аспект статевого життя людини, який включає різноманітні психічні образи та уявлення, що сприймаються людиною як сексуально забарвлені та викликають збудження. Наведено основні погляди на механізми їх формування, зокрема тлумачення в межах психоаналітичної концепції та формування фантазій як результату научіння, взаємозв'язок частоти сексуальних фантазій та рівня статевих гормонів. Визначено, що сексуальні фантазії належать до когнітивних процесів, які беруть безпосередню участь у циклі формування сексуальної реакції. Окреслено основні функції сексуальних фантазій, серед яких посилення сексуального збудження, зняття напруги, втеча від реальності, прогнозування, підвищення самооцінки та інші. Розкрито основні змістові аспекти, такі як фантазії романтичного характеру, фантазії з сексуальними експериментами, фантазії з ідеями підкорення або домінування, садо-мазохістські фантазії, фантазії з тематиками вуаєризму, проміскуїтету, групового сексу або зміни постійного партнера. Також описано відмінності між жіночим та чоловічим типом фантазування. Розкрито основні проблеми, які можуть бути пов'язані з сексуальними фантазіями: наявність нав'язливих фантазій, наявність девіантних фантазій, специфіка фантазування у осіб з травматичним досвідом, специфічний зв'язок між характером емоційних фантазій та особистісними особливостями. Коротко розглянуто основні способи психотерапевтичної роботи з сексуальними фантазіями залежно від типу проблеми: аверсивну психотерапію, позитивне підкріплення бажаного досвіду, десенсибілізацію та переробку рухами очей, психоаналітичну інтерпретацію змісту фантазій, техніку емоційної екстракції.

КЛЮЧОВІ СЛОВА: сексуальні фантазії, функції сексуальних фантазій, зміст сексуальних фантазій, сексуальне здоров’я

\section{СЕКСУАЛЬНЫЕ ФАНТАЗИИ: ОБЗОР ОСНОВНЫХ НАУЧНЫХ ИССЛЕДОВАНИЙ}

Палий В.С.

Киевский национальный лингвистический университет улииа Большая Васильковская, 73, Киев, 03680, Украина Данная публикация посвящена анализу основных классических и новейших исследований изучения сексуальных фантазий. В ней представлено современное понимание данного феномена, согласно которого сексуальные фантазии - это неотъемлемый аспект сексуальной жизни, что включает различные психические образы и представления, которые воспринимаются 
человеком как сексуально окрашенные и вызывающие возбуждение. Приведены основные идеи относительно их формирования, в том числе, толкование в рамках психоаналитической концепции и формирование фантазий как результат научения, взаимосвязь частоты эротических фантазий и уровня половых гормонов. Определено, что сексуальные фантазии относятся к когнитивным процессам, которые принимают участие в цикле формирования сексуальной реакции. Описаны основные функции сексуальных фантазий, среди которых усиление сексуального возбуждения, снятие напряжения, побег от реальности, прогнозирование, повышение самооценки и другие. Раскрыты основные содержательные аспекты, такие как фантазии романтического характера, фантазии с сексуальными экспериментами, фантазии с идеями подчинения или доминирования, садо-мазохисткие фантазии, фантазии с тематиками вуаеризма, промискуитета, группового секса или смены постоянного партнера. Также описаны отличия между женским и мужским типом фантазирования. Раскрыты основные проблемы, которые могут быть связаны с сексуальными фантазиями: наличие навязчивых фантазий, наличие девиантных фантазий, специфика фантазирования у людей с травматическим опытом, специфическая связь между характером сексуальных фантазий и личностными особенностями. Коротко рассмотрены основные способы психотерапевтической работы с сексуальными фантазиями зависимо от типа проблемы: аверсивную психотерапию, позитивное подкрепление желаемого опыта, десенсибилизацию и переработку быстрыми движениями глаз, психоаналитическую интерпретацию содержания фантазий, технику эмоциональной экстракции.

КЛЮЧЕВЫЕ СЛОВА: сексуальные фантазии, функции сексуальных фантазий, содержание сексуальных фантазий, сексуальное здоровье

Problem statement. Until recently, domestic research field paid no attention to the sphere of sexual fantasies. Sexual imagination was regarded as something quite understandable and not worthy of attention. Major scientific works were focused on more practical objectives - prevention and treatment of sexual disorders, maintaining sexual health, prevention of sexual disharmonies. Within these scientific researches, sexual fantasies appeared almost every time, however, tangentially connected to the main theme. Today, regarding the development of a new scientific field, such as the psychology of sexuality, and a wide social demand for counseling and psychotherapy, this topic is very important, since it has both diagnostic and practical potential. Additionally, foreign approach extensively applies methods that focus mainly on transformation (changing of frequency, content or emotional reactions) of sexual fantasies; this is the reason why the overview of works with foreign and domestic experience is highly important, first of all, from a practical perspective. The purpose of this publication is a systematization of existing classical and current studies on the topic of sexual fantasies. The objectives of this article include the presentation of a modern definition of sexual fantasies, analysis of understanding of their nature, identification of their place in an individual's sexual life, an overview of main functions and analysis of main contextual forms, description of sexual problems related to sexual fantasizing.

Modern scientific understanding of a phenomenon of sexual fantasizing. Erotic dreams, images, and fantasies are an integral part of a human's sexual life that includes various mental visions and impressions which are perceived by a person as sexual and evoke arousal (Leitenberg \& Henning, 1995a).

Sexual fantasies accompany the existing sexual life and may at times compensate for its absence, thus, erotic imagination is regarded to be one of the common forms of an individual's sexual experience (Ellis \& Symons, 1990). According to (Leitenberg \& Henning, 1995b), approximately 95\% of men and women report to have been using sexual fantasies in different contexts. As noted by (Maltz \& Boss, 1997a), people that lead a more active sexual life are distinguished with an intensive erotic imagination. According to a domestic scientists (Krishtal \& Grygoryan, 2002), sexual fantasies are an integral criterion for a sexual health of a person.

The nature of sexual fantasies formation. (Kelly, 1988; 2015) argues that sexual fantasies are a product of our consciousness and result from our life experiences, both earlier ones and the ones acquired later during a lifetime. Fantasies can be also inspired by book stories, paintings, films. (Byrne, 1977a) is the one who holds the same opinion. The scientist assumed that sexual reaction of a person may be provoked by either unconditional or acquired through learning erotic stimuli. The most in-depth research of sexual fantasies was conducted by psychoanalysts. (Freud, 1905; 1996) viewed sexual fantasies as something that precedes socially unacceptable sexual behavior. According to his views, sexual fantasies compensate for a behavior act that was 
not implemented. Deviant sexual fantasies are an immature expression of a sexual desire and are an obstacle to mature sexuality development. However, the idea was refuted as most people, including the ones who are quite satisfied with their sexual life and do not have any disorders, experience sexual fantasies. (Wilson \& Lang, 1981), in their studies, revealed a correlation between the frequency of fantasies and the level of satisfaction with sexual life. Similarly, (Hariton, 1973) conducted a research aimed at defining the personal features of women and comparison of these features with the sexual fantasies frequency and content. Thus, more creative, emancipated, aggressive and impulsive women had a more fertile erotic imagination than more feminine women, who experienced the sexual fantasies significantly lesser number of times. Recent data give reasons to assume the possibility of existing of a correlation between the frequency and diversity of sexual fantasies and the level of sex hormones. According to (Kocharian, 2016), that undertook a study of foreign researches on this topic, there is a correlation between the intensity and vividness of imagination and the level of testosterone. However, the content of sexual fantasies is also an interest. A well-known psychoanalyst (Kernberg, 1998) believes that the content and the extent of prevalence of sexual fantasies in one's mental activity are a criterion that indicates the experience of going through psychosexual development stages and sexuality formation features. Correspondingly, masochistically themed fantasies, fantasies with sadistic tendencies, voyeurism or exhibitionism, promiscuity, threesome sex tendencies, may give a quite exhaustive piece of information about the relationship experience of a child with significant adults at the earlier development stages.

The place of sexual fantasies in the human sexual response cycle. Sexual fantasies play an important role in the sexual response cycle. One of the most famous sexology developments is a human's sexual response cycle that was offered by (Masters \& Johnson, 1966), and which consists of the excitement phase, plateau phase, orgasmic phase, and resolution phase. However, it is possible to say that not everything has to be explained in the words of physiological reactions. Exploring the emergence of a sexual arousal, researchers reached the conclusion that bare physiological stimuli are not enough, they are often accompanied by cognitive productions.

In the year 1977, (Byrne, 1977) offered a sexual reaction cycle model which defines excitement, affective reactions, and cognitive processes as sexual behavior determinants. These stimuli may provoke physiological sexual arousal, emotional reactions and cognitive responses as sexual fantasies. Affective reactions, excitement, and cognitive processes lead and motivate instrumental actions. Sexual fantasies are a part of cognitive processes and, according to the author of the theory, take part in the shaping of sexual response cycle.

J. Bancroft (1989) developed a theoretical scheme of sexual arousal research which he named psychosomatic sexual circle. He believed that sexual arousal consists of four basic elements: desire, central excitation, peripheral excitation, and genital reaction. Sexual excitement becomes erotic, and the stimulus acquires sexual content as a result of cognitive image transformation that may include the processes of evaluations, interpretation or content analysis. Cognitive processes, according to the researcher, are a trigger of sexual arousal. Emotional excitement becomes erotic only if it is included in the appropriate motivation system, that is, is perceived and assessed as a sexual one.

American sexologists B. Zilbergeld and C. Ellison (1980) offered a psychological formula of a sexresponse cycle that comprises five elements: interest, excitement, physiological readiness, orgasm, and satisfaction. Sexual fantasies can be traced in the first two stages.

Functions of sexual fantasies. Sexual fantasies fulfill a wide range of different functions. Fantasies may boost self-esteem, retain emotions, substitute real sexual behavior or simply help gain sexual release.

Sexual images and fantasies, as noted by an american psychologist (Byrne, 1977b), fulfill four main functions:

- Sexual fantasies are means of acquiring knowledge;

- Sexual fantasies play a role of a sexual behavior trigger; 
- Sexual fantasies expand the borders and capacities of sexual satisfaction, enrich the repertoire of our sexual behavior and supplement it with novel nuances;

- Erotic imagination enables individuals to overcome stringent borders of reality and makes it possible to get experiences that may be unavailable physically.

Sexual fantasies strengthen both psychological and physiological sides of a sexual reaction in multiple ways: they resist boredom, concentrate thoughts and feelings, thus, prevent distraction and facilitate tension, boost self-esteem, since particularly in a dream one can imagine themselves as a perfect partner disregarding blemishes of their body (Masters, Johnson \& Kolodny, 1985).

In sexual fantasies, a person creates a safe, credibly secure environment that can unleash imagination and feelings. They are secured at least to the point that no one knows about them, therefore, strangers are untraceable to trace them. The awareness that these events are fictional and unreal frees from personal responsibility. Hence, fantasizing, a person reduces the strain of defense mechanisms to some extent and often demonstrates unconscious stereotypical images. Regarding the fact that sexual fantasies are mainly related to such kind of events and behavior that, if encountered in reality, could be judged as unacceptable and illicit, the emerging need for a safety as a background where the arousal occurs is completely understandable.

Often fantasies serve as a way of predicting future events and are an attempt to prepare for them, for what and how to expect, how to act. This function of sexual fantasies is extremely significant especially for youth and people with little sexual experience. Replaying in imagination a certain scene several times, a person can invent a way to minimize all challenges and can even partially dispose of embarrassment, astonishment, shame. Of course, when the fantasy becomes a reality it may prove to be different from dreams, nevertheless, using imagination as a rehearsal, one feels calmer and more confident.

A lot of people falsely understand the nature of sexual fantasies assuming that a person desires to transform into reality any of the fantasies. It frequently happens that fantasies exist only as a form of an imagination result and do not require realization.

In many cases, sexual fantasies are employed to generate or strengthen sexual arousal. Sexual fantasies are often necessary as a first impulse that induces arousal. For some individuals, they are essential to proceed from a low level of excitement to a more passionate state.

It was ascertained that the majority of women that are aroused by the fantasies that portray such types of sexual activity as violence, zoophilia, incest, sadomasochism, say they do not possess any desire to make them into reality. A lot of people argue that they do not want their fantasies to come true, although, there exist individuals that do otherwise. What makes a person to be inclined to the one or the other option remains unclear, however, may be determined by the following: 1) the severity of an erotic desire these fantasies provoke; 2) the partner's ability to understand and be reliable; 3) the self-image of a person and 4) the level of queerness of the fantasy.

The content of sexual fantasies. Sexual fantasy suggests the initiation of some sexual scenario. The definition of a sexual scenario was introduced to sexology by American sociologists (Gagnon \& Simon, 2011). Sexual scenario essentially means three different aspects:

- The combination of social norms that regulate sexual behavior of the members of a community;

- The interpersonal relationship where these cultural norms are implemented;

- The combination of erotic motives and advantages specific to a person and that are indissolubly connected to one's Self.

These aspects may not coincide but are always related to each other. Every person has got not a one but a number of scenarios. Firstly, these are the fantasies that one never wants to make into reality or implement to the full extent. Secondly, they are plans of a behavior that a person steadily implements. Thirdly, they are the intermediate benchmarks that emerged and developed as a result of a sexual interaction. Fourthly, they represent former sexual experience. 
There exist different classifications of sexual fantasies, and often certain fantasies are difficult to be classified under some groups. However, there are particular criteria that allow differentiating fantasies according to the content.

The most popular fantasies are related to certain experiments: it means to imagine something that never happened in real life. In sexual dreams of such type, a person may experiment with roles in the scenes and forms of receiving sexual satisfaction. These actions may not require implementation into reality.

Another contextual feature of a fantasy is submission which means strength of a partner, physical or moral. These may be the fantasies about seduction or direct coercion.

Infliction of pain or the feeling of it may be a source of a sexual satisfaction. In sadomasochistically themed fantasies a person imagines physical cruelty directed at themselves or other people. Physical cruelty implies beating, tying up, burning, shackling and others. In these fantasies, pain and its intensity are vividly described. Satisfaction, in this case, is directly proportional to the suffering of a victim. Men and women may experience these fantasies without a need for realization.

Rape themed fantasies cause the most confusion among broad masses. Women experience them more frequently. The most reasonable way to interpret rape themed fantasies is to regard them as a means for some women to make sure they are sexually passive, thus, their behavior corresponds with a cultural stereotype. Additionally, this type of fantasies frees a victim from a personal responsibility for a received sexual satisfaction.

All too calm romantic fantasies drastically differ from the rape themed ones. These scenarios are generally designed as accidental acquaintances under nearly perfect circumstances - a cozy garden, a beautiful sea beach, a tropical paradise. These conditions foster the outburst of a romantic feeling that gradually transforms into a sexual foreplay. After such an outburst of passion, the couple is not connected by anything.

Common are also the fantasies that include a different partner, who may be imaginary, a former one or a real acquaintance. One of the varieties of the fantasies that include a different partner is a fantasy of having sex with a celebrity.

The other type of fantasies, closely related to the one with a partner change, is scenes of a group sex. Such fantasies can be thoroughly planned orgies featuring friends extending to the scenarios of fantastic life or other people and visions. In some group sex themed fantasies actions have a bisexual nature, while in others they are purely heterosexual.

Pretty popular are the fantasies about observing other people having sex. The pristine form of this fantasy does not imply an observer taking part in a sexual intercourse, although this person may attract the attention of the surrounding people. In variations of this theme, an observer reaches an intensive sexual arousal and joins the participants of a sexual intercourse.

According to the data acquired by Hunt (Hunt, 1974), the most common scenarios of sexual fantasies of men and women during masturbation are: sexual intercourse with a loved one, sexual intercourse with a stranger, sex with two or more partners of an opposite sex, sexual actions that are never transitioned into reality, coercion of a partner into a sexual relationship, sex under coercion, homosexual contact.

Female and male fantasies feature both common traits and certain differences. Common traits include the frequency of fantasizing; also, male and female fantasies are characterized by a rather broad range of actions. However, there exist gender-based differences of a content of fantasies. Thus, male fantasies have a more active nature and are more oriented on a woman's body, on what he wants to do to it. Female fantasies, in their turn, are more passive and are concentrated on the fact of a partner's interest and his activity. The main role in male fantasies plays the sexual intercourse itself, while the focus of female fantasies is on the atmosphere and the emotional aspect. Men experience fantasies featuring two or several partners more often than women. Scenes of dominance are more common for male fantasies whereas themes of submission are common for women (Leitenberg \& Henning, 1995c). 
Ziegler \& Conley (2016) indicate that females are more likely than males to have submissive fantasies. According to the scientists, such distinctiveness is caused by gender expectations regarding the manifestations of females' sexuality and is the result of socialization in this issue. Also, they believe that often in a society the manifestations of open sexuality can be perceived as manifestations of promiscuity, so the presence of submissive fantasies is an attempt to pass the responsibility to a partner. In such fantasies, the initiative belongs to a man, and not to a woman, and therefore she will not suffer from the reproof of conscience regarding her own possible promiscuity and will not worry about her own possible mismatch with social expectations.

Problems related to the content of fantasies. The erotic imagination of a person is far broader and more varied than the real behavior. Moreover, it includes a range of prohibited actions that may necessitate disapproval and rejection in real life, in particular, a feeling of guilt. The research data (Follingstad \& Kimbrell, 1986) suggest that people, who associate sex with a feeling of guilt, experience less arousal from sexual fantasies. Individuals that went through a sexual abuse in childhood often produce compensatory sexual fantasies with the purpose of 'detouring' the traumatic experience and intensify sexual excitement, although they do not always succeed and only repeatedly immerse in the trauma (Boss \& Maltz, 1997b). Furthermore, the research conducted on the people who underwent sexual abuse in adulthood showed that sexual fantasies featuring dominance or submission are often accompanied by negative feelings (Renaud \& Byers, 2006). Besides, some suggestions posit that the existence of explicitly deviant fantasies, for example, explicitly violent fantasies about engaging in sex with underage individuals, may be regarded as a potential risk in a context of committing sexually-based crimes (Bartels \& Gannon 2011). Individuals who exhibit a low level of sexual drive often have frugal sexual fantasies, that is why one of the work direction with their difficulties may involve the development of positive sexual fantasies. In the 1990s of XX century, a method of 'sexual healing', that implied a separate stage of working with sexual fantasies, was developed (Maltz, 1992, 2000). At that very time, the counseling strategies directed at reducing the arousal from deviant sexual fantasies were introduced. At the heart of these strategies are a mechanism of aversion and positive reinforcement. The deviant images were 'bound' to odious stimuli, whereas 'positive' ones were supported with genitalia stimulation (Laws \& Marshall, 1991). The other data confirm the existence of such methods directed at treating the unwelcome and discomforting images as the method of eye movement desensitization and reprocessing (EMDR) (Bartels, Harkins, 2018). Psychological tradition uses interpretation method that allows identification and a deeper understanding of the roots of such visions and fantasies.

Recent researches study the relationship between the nature and content of sexual fantasies with the peculiarities of the organization of personality. So, in a study by Baughman, Jonason, Veselka \& Vernon (2014), the relationship between the dark triad and the features of sexual fantasies was studied. It was found that psychopathy was the most strongly correlated with general sex drive as well as fantasies that contained exploratory, impersonal, and sadomasochistic themes. In the studies of Birnbaum (2007), it was discovered that the associations between attachment orientations and sexual fantasies were discovered. More anxiously attached women were particularly likely to report extrapair fantasies, while more anxiously attached men were especially likely to report romantic fantasies. Attachment avoidance was negatively related to romantic themes, especially among men. Recent latest data allow deeper understanding of the nature and frequency of sexual fantasies influence on sexual behavior in general and the features of building the partnerships.

A considerable difference between erotic imagination and real personal sexual behavior may be a sign of a problematic sexual life. This means that a person cannot, or does not, allow themselves to realize their sexual scenario, they live not by their own rules, feel not free. In some cases, this may be a consequence of general rigidity, attitudes, inability to implement changes, fixation on the previous development stages, unrealistic level of aspirations; in other cases - a conflict between personal erotic preferences and sociocultural norms when satisfaction of individual's demands may lead to problems with the law, public morality. Sometimes dominance or submission fantasies may not coincide with the worldview and personal cultural norms, thus, be strictly internally condemned causing negative feelings and frustrating real sexual behavior 
(Moyano \& Sierra, 2014). Likewise, while working with sexual dreams and fantasies an emotion extraction technique, which was developed as part of experiential psychotherapy, can be utilized (Kocharian, 2012). With the help of this technique, a client not only profoundly understands the cause of these fantasies but also can approach those traumatizing experiences that serve as hurdles to a self-actualization tendency. Thus, within this approach, a specialist works not only with a symptom, with deviant or obsessive fantasy or a feeling of guilt and shame for their sexual dreams. The work with emotion extraction enables one to approach deep underlying reasons for these visions and to work directly with them.

Conclusion. Concluding, it must be said that sexual fantasies are an inseparable aspect of a human sexual life. Their development is determined by various factors: level of hormones, early childhood experience and life in adulthood. They fulfill a quite broad range of functions that allow one to have a more harmonious sexual life. Sexual fantasies have different content, and often a particular pattern has a diagnostic nature, although it may not be always universal. Sometimes sexual fantasies may be explicitly deviant or obsessive, be accompanied with a feeling of guilt, hence, they become o focus of a psychotherapy within different frameworks' perspective.

\section{REFERENCES}

Bancroft, J. (1989). Human Sexuality and Its Problems. US: Churchill Livingstone.

Bartels, R. M., \& Gannon, T. A. (2011). Understanding the sexual fantasies of sex offenders and their correlates. Aggression and Violent Behavior, 16(6), 551-561. http://dx.doi.org/10.1016/j.avb.2011.08.002

Bartels, R. M., Harkins, L., Harrison, S. C., Beard, N., \& Beech, A. R. (2018). The effect of bilateral eye-movements versus no eye-movements on sexual fantasies. Journal of Behavior Therapy and Experimental Psychiatry, 59, 107-114. http://dx.doi.org/10.1016/j.jbtep.2018.01.001

Baughman, H. M., Jonason, P. K., Veselka, L., \& Vernon, P. A. (2014). Four shades of sexual fantasies linked to the Dark Triad. Personality and Individual Differences, 67, 47-51. http://dx.doi.org/10.1016/j.paid.2014.01.034

Birnbaum, G. E. (2007). Beyond the borders of reality: Attachment orientations and sexual fantasies. Personal Relationships, 14(2), 321-342. http://dx.doi.org/10.1111/j.1475-6811.2007.00157.x

Byrne, D. (1977). The imagery of sex. In J. Money \& H. Musaph (Eds.), Handbook of sexology (pp. 327-350). Amsterdam, The Netherlands: Elsevier.

Ellis, B. J., \& Symons, D. (1990). Sex differences in sexual fantasy: An evolutionary psychological approach. Journal of Sex Research, 27(4), 527-555. http://dx.doi.org/10.1080/00224499009551579

Follingstad, D. R., \& Kimbrell, C. D. (1986). Sex fantasies revisited: An expansion and further clarification of variables affecting sex fantasy production. Archives of Sexual Behavior, 15(6), 475486. http://dx.doi.org/10.1007/BF01542312

Freud, S. (1905; 1996). Drei Abhandlungen zur Sexualtheorie. Fischer: Frankfurt am Main.

Gagnon, J. \& Simon, W. (2011). Sexual Conduct. US: Transaction Publishers.

Hariton E.B. The sexual fantasies of women // Psychology Today. - 1973, March. - P. 39-44.

Hunt, M. (1974). Sexual behavior in the 70's. Chicago: Playboy Press.

Kelly, G. F. (1988; 2015). Sexuality today. NY, US: McGraw-Hill Publishing Company.

Kernberg, O. (1998). Love Relations: Normality and Pathology. Yale University Press.

Kocharian, A. S. (2012). «Техника эмоциональной экстракции» в работе со сновидной продукцией ['Emotion extraction' in work with dreams], Nauchno-prakticheskiy zhyrnal 'Psyhoterapia', 10, 41-45. (In Russian)

Kocharian, G. S. (2016). Сексуальные фантазии: современные представления [Sexual fantasies: modern approches], Zdorov'e muzchiny, 1,59-69 (In Russian)

Krishtal, V. V. \& Grygiryan, C. P. (2002). Сексология [Sexology]. - Moscow: Perse (In Russian).

Laws, D. R., \& Marshall, W. L. (1991). Masturbatory reconditioning with sexual deviates: An evaluative review. Advances in Behaviour Research and Therapy, 13(1), 13-25. http://dx.doi.org/10.1016/0146-6402(91)90012-Y

Leitenberg, H., \& Henning, K. (1995). Sexual fantasy. Psychological Bulletin, 117(3), 469496. http://dx.doi.org/10.1037/0033-2909.117.3.469

Maltz, W. (2000). Sexual healing from sexual abuse. Siecus Report, 29, 17-23.

Maltz, W. (1992). Sexual healing journey: A guide for survivors of sexual abuse. New York: Harper Perennial. 
Maltz, W, Boss, S. (1997) In the Garden of Desire: Women's Sexual Fantasies as a Gateway to Passion and Pleasure. US: Broadway.

Masters, W., Johnson, V. (1966). Human sexual responce. US: Lippincott Williams \& Wilkins.

Masters, W., Johnson, V., \& Kolodny, R. C. (1985). Human sexuality. NY, US: Little, Brown and Company.

Moyano, N., \& Sierra, J. C. (2014). Fantasías y pensamientos sexuales: Revisión conceptual y relación con la salud sexual [Fantasies and sexual cognitions: Conceptual review and relation to sexual health]. Revista Puertorriqueña de Psicología, 25(2), 376-393.

Renaud, C.A., \& Byers, S.E. (2006). Positive and Negative Cognitions of Sexual Submission: Relationship to SexualViolence. Archives of Sexual Behavior, 35(4), 483-490. http://dx.doi.org/10.1007/s10508-006-9046-2

Wilson, G. D., \& Lang, R. J. (1981). Sex differences in sexual fantasy patterns. Personality and Individual Differences, 2(4), 343-346. http://dx.doi.org/10.1016/0191-8869(81)90093-3

Ziegler, A., \& Conley, T.D. (2016). The importance and meaning of sexual fantasies in intimate relationships. In K. Aumer (Ed.), The psychology of love and hate in intimate relationships (pp. 29-45). Cham, Switzerland: Springer International Publishing.

Zilbergeld, B., \& Ellison, C.R. (1980). Desire discrepancies and arousal problems in sex therapy. In S.R. Leiblum \& L. Pervin (Eds.), Principles and practice of sex therapy (pp. 65-106). New York, NY: Guilford Press. 